\title{
How COVID-19 Pandemic Changes Job Seeker Perceptions about an Indonesian Giant Startup as Top Employers: Perceptions of Generation $\mathbf{Z}$
}

\author{
Dediek Tri Kurniawan ${ }^{1, *}$ Sopiah $^{1}$ Lohana Juariyah $^{1}$ Afwan Hariri Agus Prohimi ${ }^{1}$ \\ Yesiana ihda Kusnayain ${ }^{1}$
}

\author{
${ }^{1}$ Department of Management, Universitas Negeri Malang \\ *Corresponding author. Email: dediek.kurniawan.fe@um.ac.id
}

\begin{abstract}
The COVID-19 pandemic has caused some technology-based startups to collapse. In recent years, startups have emerged as the top employer in labor competition. Moreover, COVID-19 has pushed technology-based startups to reduce their employees. Enforcement Large-scale social restrictions have reduced the use of ride hailing or digitalbased transportation about $75 \%$. These conditions affect employer branding that has been built a long time ago. The organization needs to manage its image to maximize recruiting effectiveness and attract job seekers or applicants. This research purpose of examining the impact of employer branding and corporate reputation on the intention to apply to an Indonesian giant startup through a person-organization fit. This research was conducted based on data from 570 business students at the State University of Malang, Indonesia. This study tried to build a more comprehensive dimension of employer branding than previous study. The result of this study confirmed the positive relationship between several dimensions of employer branding (work values, diversity, and salary and incentives) and intention to apply.
\end{abstract}

Keywords: Employer Brand, Corporate Reputation, COVID-19, Business Student, Gen Z.

\section{INTRODUCTION}

The COVID-19 pandemic has caused some technology-based startups to collapse in the world. Based on Layoffs.fyi tracker, globally there are around 492 start-ups and 63,714 employees in the world who were laid off during the period 11 March-8 June 2020. Startups in the transportation sector have the highest number of layoffs. The lockdown policy from government lockdown policy into this sector is difficult to survive. In April 2020, worldometer.info recorded about 1,015,466 confirmed cases of COVID-19, 53,190 deaths, 212,229 recovered. Covid-19 spread rapidly to 240 countries. This year (2020) is a challenging period for all countries in the world. Before COVID-19, technology-based-startups have become an essential part of business in Southeast Asia (SEA). Home for 570 million people, Southeast Asia's largest economies comprising Indonesia, Malaysia, the Philippines,
Thailand, Vietnam and Singapore are among the fastestgrowing markets in the world. The Southeast Asian Internet economy predicted about $\$ 100$ billion. At this rate, the Southeast Asian Internet economy is on track to hit $\$ 300$ billion by 2025 . They were being estimated that the Southeast Asian Internet economy has leapt nearly $40 \%$ from last year to exceed $\$ 100$ billion in gross merchandise value (GMV) in 2019 across the Online Travel, e-Commerce, Online Media and RideHailing sectors. With a 33\% compounded annual growth rate (CAGR), the value of the Internet economy has more than tripled between 2015 and 2019.

Based on the e-economy SEA report by Google and Temasek, Indonesia is the most significant digital economy country in Southeast Asia. Indonesia's internet economy estimated $\$ 40$ billion in 2019 where this is quadrupled more significantly since 2015 [1]. Indonesia's rapid digital economy growth makes Indonesia's digital economy predicted to increase about 
$\$ 130$ billion. The size of Indonesia's digital economy is even more than double that of Vietnam as the second player in SEA digital economy, which reached \$12 billion in 2019. Based on a report by AT Kearney and Google, foreign investment in Indonesia for startupbased technology is about USD\$ 3 billion in 2017. The number significantly increased from 2012, about USD 44 million.

Some countries, including Indonesia, are facing the pandemic COVID-19 as a challenge including technology startups. Bank Indonesia (BI) viewed the coronavirus pandemic (COVID-19) as potentially increasing the risk of global economic recession this year. Corona has disrupted business and economic activities in Indonesia. Economic pressures will emerge as a result of this pandemic. Based on the report "Macroeconomic Analysis Series: Indonesia Economic Outlook" by LPEM FEB UI, Indonesia GDP of 2020 is projected to grow slower at $2.4 \%-2.6 \%$ in 2020 [2]. Indonesia's labour ministry recorded that about 1.2 million workers were laid off from 74,430 companies because of the COVID-19 pandemic. Based on data from the Ministry of Manpower and BPJS Ketenagakerjaan (Social Security Provider), there are 2.8 million workers directly affected by COVID-19. They consist of 1.7 million formal workers laid off and terminated 749.4 thousand employment contracts. Besides, there were 282 informal workers whose businesses were disrupted. Based on data form layoff.fyi, there are 5 startups in Indonesia that have cut their employees with 450 employees laid off [3]. Enforcement of large-scale social restrictions have reduced the use of ride hailing or digital-based transportation about $75 \%$.

The competition in the labour market encourages an organization to understand the importance of employer branding. The organization needs to manage its image to maximize recruiting effectiveness and attract job seekers or applicants [4]. Previous research also proves that an organization's image as an employer is a strong predictor of applicants' interest[5]. Organizational attributes were positively correlated with the intention to apply [6]. Other research also showed that organizational attribute and job characteristic significantly related with the intention to apply [7]. Organization's image as an employer is a strong predictor of applicant' attraction [5]. In getting the prospective employee in the labor market, the company must adapt to environmental change including in labor attributes. After discussing Generation Y, the company is preparing to welcome a new generation, Gen $\mathrm{Z}$. Generation Z born after 1995s until the 2010s. They have different characteristics comparing previous generations (Millennials, Generation $\mathrm{X}$, or Baby Boomers). Generation Z is also known as "Gen Next" or "Gen I" [8]. While Milllenials had to learn and adapt to technology (new devices) and the internet that changes the way the world operates, Generation $\mathrm{Z}$ is born and grows with technology [9]. For Gen Y, organization branding and image influenced the intention to join with an organization [10]. They will judge the organization and create a decision to apply or to join. Millennial have also focused on their work values which are very important for them to career's decision and career choice [11]

This research purposes to examine the impact of employer branding and corporate reputation on the intention to apply through a person-organization fit in business student about Indonesia giant startup in COVID-19 pandemic. The Indonesia giant startup in this study is Gojek. This research will be conducted on business students at the State University of Malang. This study is expected to be able to help build a foundation for the implementation of various factors of the employers' brand that are considered important by potential job applicants, especially in the Indonesian context. Gojek is one that was under pressure during the COVID-19 pandemic because COVID-19 makes the potential number of orders in Go-ride go down. Despite the difficult situation, COVID-19 will give a space for the company to show its identity. The community is very concerned about what the company is doing in this condition.

\section{LITERATURE REVIEW}

\subsection{Employer Branding}

Employer branding is an application of the marketing principles to human resource management [12]. The employer branding defines the steadily designed and executed process of developing and maintaining the excellent reputation of the company with its essential component through sending the signals to stakeholders through the behaviour, communication and imagery using the corporate identity [13]. Employer branding is "a targeted, long term strategy to manage awareness and perception of employees, potential employees, and related stakeholders with regards to a particular firm" [4, 44]. Employer branding is a method from a company to attract high potential talent in the labour market. Organizations must try to make them different from competitors and to be seen as attractive employers for the prospective applicant or current employees [14].

\subsection{Corporate Familiarity}

Company familiarity with the employer brand is defined as "the level of awareness that a job seeker to an organization" [15]. Familiarity with an employer brand is relevant to potential employees who are not actively searching for a job as well as for current employees. Familiarity with the employer is an essential part of the 
employer-employee relationship, and previous research acknowledged this role for existing employees [15]. It proposed that things that are familiar to people cause them to experience a "glow of warmth" and feeling of intimacy [16]. Support for this idea has been found in research on the "mere exposure" phenomenon [16]. This phenomenon occurs when there is an increase in liking caused by increased familiarity with previously neutral stimuli.

\subsection{Corporate Reputation}

Corporate reputation in this instance can be a critical source of knowledge for existing employees to learn how their employer is perceived externally and how they should perform in their job [17]. Reputation is the sum values that stakeholders attribute to a company, based on their perception and interpretation of the image that the company communicates over time [18]. The study reported that since the 1990 's, reputation is perceived as a strategic resource for a company that can affect its financial performance and reputation is "a concept related to an image, but one that refers to value judgments among the public about an organization's qualities, formed over a long period, regarding its consistency, trustworthiness and reliability [19]. Reputation as assets that include "quality of products and services, ability to innovate, value as a long-term investment, financial stability, ability to attract, develop, retain talent; use of corporate assets, and quality of management" [19]. Nguyen and Leblanc (2001) define reputation as "an estimation of the consistency over time of an attribute of an entity" [20].

\subsection{Person Organizational Fit}

The concept of person-organization fit (POF) is concerned with matching individual personalities, values, goals, attitudes and needs with organizational values, demands and culture [21]. POF also focuses on the compatibility between individual values and organizational values $[22,23]$. The consequences of POF have shown a significant relationship with important individual outcome variables such as job satisfaction, organizational commitment, and performance [23]. The person-organization fit is related with how an individual chose an organization (including company) to join in the recruitment process [7]. The meaning of fit can be interpreted when someone brings the same skills, values, and perspectives to the organization or the conditions in which a person brings novels, skills, values, and perspectives that are unique to the organization [22]. Person-organization fit suggests that graduates' preferences for organization attributes will influence their intentions to apply [7].

\subsection{Intention to Apply}

In general, intentions are determined by beliefs, attitudes, subjective norms, and perceptual control [24]. Each applicant has their own intention to apply in the job place, in between, to have an organization as a positive place to work [25]. Intention to join is a decision of intent to join that any candidate takes to pursue an organization as its employer [26]. Several studies have tried to examine potential variables like employer branding that are able to predict the desire to apply or join a company $[7,25,26]$. In addition, the company reputation is also a strong predictor for a person to accept an offer from a company to join [27].

\section{RESEARCH METHOD}

The research targeted about 500 students from business schools for bachelor degree in Universitas Negeri Malang. This study targeted students from management, accounting, and the economics department. The collecting method used a combination of questionnaires that were distributed in online channels (email, WhatsApp's, and other social media). The researchers prevent the face-to-face interaction to reduce COVID-19 risk. The sample size in this research based on the assumption minimum sample 200 to effectively employ Structural Equation Modelling (SEM) [28]. In other references, the size in Maximum Likelihood estimation is minimum $5 \mathrm{x}$ the number of

Table1. The Development of Employer Branding Dimension

\begin{tabular}{|c|c|c|}
\hline Author & Dimension & Items/Dimension \\
\hline $\begin{array}{l}\text { Berthon, Ewing, \& Hah } \\
(2005)\end{array}$ & $\begin{array}{l}\text { interest value, social value, economic value, development value, and } \\
\text { application value. }\end{array}$ & $\begin{array}{l}25 \text { items } \\
5 \text { dimensions }\end{array}$ \\
\hline $\begin{array}{l}\text { Schlager, Bodderas, Maas, } \\
\text { \& Cachelin (2011) }\end{array}$ & $\begin{array}{l}\text { economic value, development value, social value, diversity value, and } \\
\text { reputation value. }\end{array}$ & $\begin{array}{l}24 \text { items } \\
5 \text { dimensions }\end{array}$ \\
\hline Alniacik \& Anliacik (2012) & $\begin{array}{l}\text { social value, market value, economic value, application value, } \\
\text { cooperation value, and working environment }\end{array}$ & $\begin{array}{l}20 \text { items } \\
6 \text { dimensions }\end{array}$ \\
\hline $\begin{array}{l}\text { Sivertzen, Nilsen, \& } \\
\text { Olafsen (2013) }\end{array}$ & $\begin{array}{l}\text { interest value, social value, economic value, development value, and } \\
\text { application value }\end{array}$ & $\begin{array}{l}25 \text { items } \\
5 \text { dimensions }\end{array}$ \\
\hline Lee at al (2018) & $\begin{array}{l}\text { Work Environment, the meaning of work, work growth, company } \\
\text { operation, friendship, salary and benefit, organization symbolize }\end{array}$ & $\begin{array}{l}54 \text { items } \\
7 \text { dimensions }\end{array}$ \\
\hline Tanwar \& Kumar, (2019) & work culture, salary \& incentives, diversity, and ethics \& CSR & $\begin{array}{l}19 \text { items } \\
4 \text { dimensions }\end{array}$ \\
\hline
\end{tabular}

Sources: [41], [42], [4], [43], [30] 
independent variables in the model [29]. This research will examine the impact of employer branding, corporate reputation, and person-organization fit on an intention to apply in Indonesia's Unicorn. For the method of analysis, this study used Structural Equation Model (SEM) to test the model by using LISREL.

\subsection{Measurement}

To measure intention to apply, the researcher used a scale developed by Highhouse, Lieven, and Sinar [14]. The scale consists of 5 items with five Likert-scale, $1=$ strongly disagree, $5=$ strongly agree. The example of an item is "I would accept a job offer from this company". The measurement of the person-organization fit used a scale adapted from the Tanwar \& Kumar [30]. Company reputation (or prestige of the organisation measured) with 6 items from Santiago [31]. The researcher developed a new set of dimensions to measure employer brand from previous research. The measurements of employer brand were divided into eight dimensions: salary and incentives, training and development, work culture, market value, ethics and CSR, diversity, leader capacity, and company familiarity. Four dimensions that are salary and incentives, work culture, ethics and CSR, and diversity adopted from Tanwar and Kumar [30]. Two dimensions (leader capacity and company familiarity) wereadopted from Myrden and Kelloway [32]. Market value used from Alnıaçık and Alnıaçık [4] and Training and development adopted from Tanwar and Prasad [33].

\section{RESULTS}

\subsection{Respondent Demographics}

After having distributed the questionnaire, the researchers received about 477 questionnaires. The total respondents who participated in this study were 477 people consisting of 127 males $(27 \%)$ and 350 females $(73 \%)$. Based on Origin, the majority of respondents were from East Java (81.97\%). Respondents who participated in this study are young people (17-29 years old), with 364 respondents of 17 - 20 years old (76\%), 110 respondents of $21-25$ years old $(23 \%)$, while 1 person was above 25 years old (1\%). The respondents' education background consists of $90.36 \%$ bachelor degree and $9.64 \%$ of associate degree.

\subsection{Respondent Demographics}

After having distributed the questionnaire, the researchers received about 477 questionnaires. The total respondents who participated in this study were 477 people consisting of 127 males $(27 \%)$ and 350 females (73\%). Based on Origin, the majority of respondents were from East Java (81.97\%). Respondents who participated in this study are young people (17-29 years

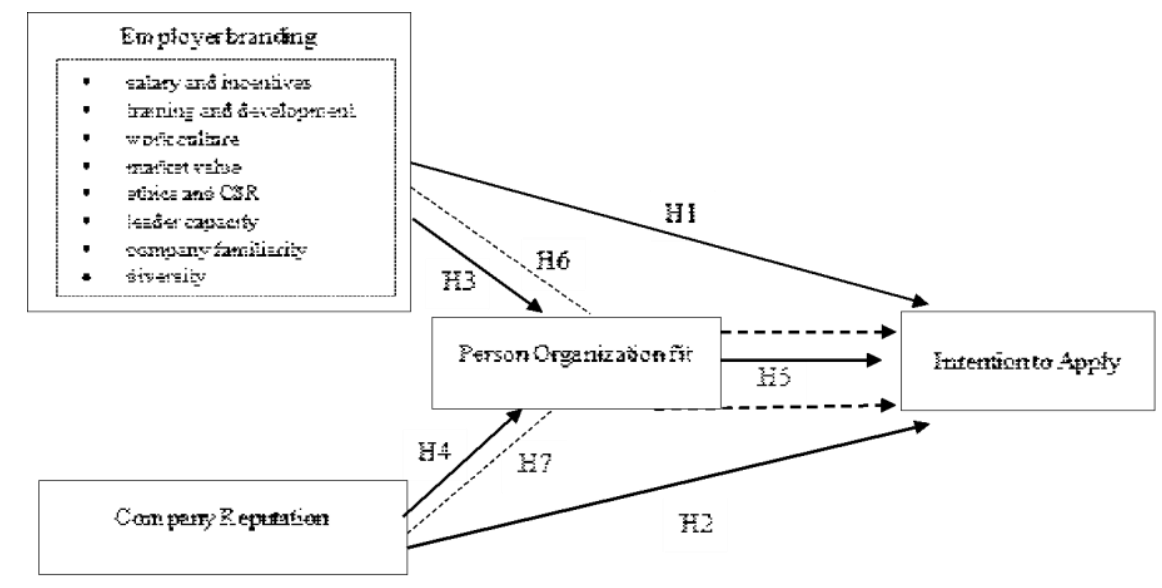

Sivertzen, Nilsen, \& Olafsen (2013), Tanwar \& Kumar, (2019)

Figure 1 Research Model

Hypothesis:

H1. Employer branding value positively influences intention to apply

H2. Company reputation positively influences intention to apply

H3. Employer branding influences person organization fit

H4. Company reputation positively influences person organization fit

H5. Person organization fit positively influences o intention to apply

H6. Person organization fit mediates the effect of employer branding on intention to apply

H7. Person organization fit mediates the effect of company reputation on intention to apply 
old), with 364 respondents of 17 - 20 years old (76\%), 110 respondents of $21-25$ years old $(23 \%)$, while 1 person was above 25 years old (1\%). The respondents' education background consists of $90.36 \%$ bachelor degree and $9.64 \%$ of associate degree.

\subsection{Validity and Reliability Test}

The researcher used Confirmatory Factor Analysis (CFA) for validity and reliability tests. The purpose of this test is to make sure all dimensions or variables are acceptable to continue to the next statistical test. Hair et al. (2006) suggest that an item will be significant if a loading factor higher than 0.5 [34]. All variables have been proper loading factor criteria $\geq 0.5$. Hair et al. (2006) suggest to use the construct reliability (CR) and the variance extracted (VE) when the model used is structural equation modeling (SEM) to show data reliability [34]. The use of CR will be proper if the item fulfills reliability criteria, the value $C R \geq 0,70$ (Nunnally and Bernstein, 1994) [16] and VE $\geq 0,5$. The result of processed data can be seen in Table 3. Based on Table 3, the CR value was in the range $0.83-0.93$ that indicates that it fulfills the reliability criteria of CR $\geq 0.7$. This condition was also found in VE. The VE value was in range $0.5-0.7$ and indicated that the variables fulfill $\mathrm{VE} \geq 0.5$. The researcher declared that the variables on Table 3 are reliable and ready for the next process.

\subsection{Descriptive Statistics}

Descriptive statistics are statistics that organize and analyze data and numbers in order to provide regular, concise, and clear data so that specific meanings can be drawn. The descriptive statistics of the summated scales from 748 respondents were presented in table 3. Table 3 showed all variables have a mean in "high category". The maximum value was in range 6.00, while the minimum value was 1.00 to 2.50 . It should be noticed that market value (MV) has the highest means. For the standards deviation, the person-organization fit is the

Table 3. Path coefficient and hypotheses test

\begin{tabular}{|l|l|r|r|l|}
\hline & Path & Coefficient & Path estimate & Decision \\
\hline H1a & Market value - Intention to apply & 0.58 & 4.50 & Supported \\
\hline H1b & Training and development - Intention to apply & 0.16 & 1.24 & Rejected \\
\hline H1c & Work culture - Intention to apply & -0.29 & -0.92 & Rejected \\
\hline H1d & Ethics and CSR - Intention to apply & 0.03 & 0.17 & Rejected \\
\hline H1e & Diversity - Intention to apply & -0.48 & -2.74 & Supported \\
\hline H1f & Salary and incentive - Intention to apply & 0.36 & 3.81 & Supported \\
\hline H1g & Company familiarity - Intention to apply & -0.08 & -1.60 & Rejected \\
\hline H1h & Leader capacity - Intention to apply & -0.04 & 0.44 & Rejected \\
\hline H2 & Company reputation - Intention to apply & 0.04 & 0.33 & Rejected \\
\hline H5 & Person organization fit - Intention to apply & 0.57 & 9.57 & Supported \\
\hline H3a & Market value - Person organization fit & 0.14 & 0.96 & Rejected \\
\hline H3b & Training and development - Person organization fit & -0.21 & -1.34 & Rejected \\
\hline H3c & Work culture - Person organization fit & 0.84 & 2.37 & Supported \\
\hline H3d & Ethics and CSR- Person organization fit & -0.47 & -2.28 & Supported \\
\hline H3e & Diversity - Person organization fit & 0.07 & 0.35 & Rejected \\
\hline H3f & Salary and incentive - Person organization fit & 0.04 & 0.33 & Rejected \\
\hline H3g & Company familiarity - Person organization fit & 0.02 & 0.30 & Rejected \\
\hline H3h & Leader capacity - Person organization fit & -0.00 & -0.01 & Rejected \\
\hline H4 & Company reputation - Person organization fit & 0.22 & 1.64 & Rejected \\
\hline Sourc: Proced
\end{tabular}

Table 4. Direct Effect, Indirect effect, dan Total effect

\begin{tabular}{|l|l|r|r|r|r|c|l|}
\hline & Path & direct effect & \multicolumn{1}{c|}{ t-value } & \multicolumn{1}{c|}{ indirect } & t-value (indirect) & total effect & decision \\
\hline H6a & MV =>POF =>IA & 0.58 & 4.50 & 0.08 & 0.99 & 0.66 & NS \\
\hline H6b & TD => POF =>IA & 0.16 & 1.24 & -0.12 & -1.30 & 0.05 & NS \\
\hline H6c & WC =>POF =>IA & -0.29 & -0.92 & 0.48 & 2.20 & 0.19 & S \\
\hline H6d & EC => POF =>IA & 0.03 & 0.17 & -0.27 & -2.14 & -0.24 & NS \\
\hline H6e & DV => POF =>IA & -0.48 & -2.74 & 0.04 & 0.35 & -0.44 & NS \\
\hline H6f & SI => POF =>IA & 0.36 & 3.81 & 0.02 & 0.34 & 0.38 & NS \\
\hline H6g & CF => POF =>IA & -0.08 & -1.60 & 0.01 & 0.30 & -0.07 & NS \\
\hline H6h & LC => POF =>IA & -0.04 & -0.44 & 0.00 & -0.01 & -0.04 & NS \\
\hline H7 & CR => POF =>IA & 0.04 & 0.33 & 0.13 & 1.60 & 0.17 & NS \\
\hline
\end{tabular}

Source: Processing Data from LISREL 8.8: S= Supported: NS=Not Supported: MV=market value: $\mathrm{TD}=$ training \& development: WC= work culture: $\mathrm{EC}=$ ethics and CSR: DIV= diversity: $\mathrm{SI}$ = salary: $\mathrm{CF}=$ company familiarity: $\mathrm{LC}=$ leadership capacity: $\mathrm{POF}=$ person organization fit: $\mathrm{IA}=$ intention to apply 
highest value with 1.02 .

\subsection{Hypothesis Test}

The researcher used path analysis to examine the hypothesis. The data result is shown in Table 4 . There are 6 hypothesis which is supported and 22 hypotheses are rejected. This indicates that Market Value $(\beta=0.58$, t-value $(4,50) \geq 1.645)$, Salary and Incentive $(\beta=0.36, t$-value $(3,81) \geq 1.645)$ and Person Organization fit $(\beta=0.57$, t-value $(9,57) \geq 1.645)$ have positive influences to intention to apply. This condition also happened toward work culture $(\beta=0.84$, tvalue $(2.37) \geq 1.645$ ) which has a positive effect on person-organization fit. On the other hand, Training development $\beta=0.16$, t-value $(1.24) \leq 1.645$ Work culture $\beta=-0.29$, t-value $(0.92) \leq 1.645$ Ethics and CSR $\beta=0.03$, t-value $(0.17) \leq 1.645$ Diversity $\beta=-0.48$, t-value $(-2.74) \leq 1.645$ Company familiarity $\beta=-0.08$, $t-$ value $(-1.60) \leq 1.645$ Leader capacity $\beta=-0.04$, $\mathrm{t}$ value $(0.44) \leq 1.645$ and company reputation $\beta=0.04$, tvalue $(0.33) \leq 1.645$ did not positive significantly affect intention to apply. This condition also happens in market value $\beta=0.14$, t-value $(0,96) \leq 1.645$ Training and development $\beta=-0.21$, t-value $(1.34) \leq 1.645$ Ethics and CSR $\beta=-0.47$, t-value $(-2.28) \leq 1.645$ Diversity $\beta=0.07, \quad$ t-value $(0.35) \leq 1.645$ Salary intensive value $\beta=0.04$, t-value $(0.33) \leq 1.645$ company familiarity $\beta=0.02$, t-value $(0.30) \leq 1.645$ Leader capacity $\beta=-0.00$, t-value $(0.01) \leq 1.645$ and company reputation $\beta=0.22$, t-value $(1.64) \leq 1.645$.

To measure H6 and H7, we used indirect analysis using LISREL 8.8, and we show in Table 9. Based on Table 9, person-organization fit can be a mediator variable in mediating the relationship between work culture and intention to apply. The result can show the value of the indirect effect of about 0.48 and $t$-value 2.20. ( $\leq 1.645)$. This result means Hypothesis H6c was Supported. This result also means Hypothesis H6a, H6b, H6d, H6e, H6f. H6g, H6i, and H7 were not supported, or the Hypotheses were rejected.

\subsection{Goodness of Fit Model}

The fit model is achieved if there are at least 4-5 indicators of goodness of fit, but the criteria must be in each absolute, incremental, and parsimony criteria. The $\chi^{2}$ of the hypothesized model 2 was accepted, $\chi^{2}$ $(\mathrm{df}=1738)=4417.11 \mathrm{p}=0.00$, indicating that the model fit the data well. The remaining fit statistics were also excellent $\quad$ (RMSEA $=0.08 ; \quad \mathrm{NFI}=0.97 ; \quad \mathrm{TLI}=0.98$; $\mathrm{CFI}=0.98 ; \quad \mathrm{IFI}=0.98 ; \quad \mathrm{GFI}=0.73$ ), thus further confirming a good fitting model.

\section{DISCUSSION}

This study confirmed the positive effect of employer branding on intention to apply in a technology startup in
Indonesia. The dimensions of employer branding that were proven to have an influence on intention to apply are dimensions of work values, diversity, and salary and incentives. However, not all dimensions have been shown to have a significant effect on intention to apply. Employer brand image was confirmed to influence a potential job applicant's intention to apply to an organization [26, 32]. In other results, work culture, diversity and ethics \& CSR have a significant effect on person-organization fit. Based on this result, CSR becomes an essential element in employer branding. CSR activities can be a means of developing and implementing the elements of employer branding in economic, functional and psychological contexts [35]. Generation Zs have the attributes: loyal, thoughtful, open-minded, an agent of change and making a difference [36]. They focused on the impact of the company in the society. They paid attention to company contribution as one of the ideal organization attributes. Companies must pay attention to company performance and corporate social responsibility in creating, changing, and improving the company's reputation to attract talented employees and attract talented applicants [37]. Employer branding is a combination of branding, CSR, and human resource management (HRM) [35]. CSR indicated that the company had a willingness to give extra to stakeholders. especially the community outside the operation context. CSR will deliver messages to external or internal parties if the company is not only focused on their interest, but also the society's interest.

On the economic value and "welfare and remuneration", they evaluate whether employers provide more than the average salary, reward package, job security and promotion opportunities [37]. Young professionals generally focus on three attractive job attributes namely personal interest, opportunities to apply knowledge and initial salary [25]. In Indonesia, salary is the key indicator in a perceived successful career, especially for fresh graduates. This study found that salary (financial aspect) was considered the most crucial for Generation $\mathrm{Z}$ in determining a company to work. Salary is one of the factors that contribute to determine the satisfaction of fresh graduates to join the organization [38]. Employer branding components such as brand trust, development value, economic value, social value and interest value become important in the organization's attractiveness in attracting applicants to join the company [25]. This study offered the most value that graduates will need to be strengthened in contributing to organization attractiveness. Millennials only pay less attention to the economic aspects including salary and promotion opportunities in employer branding in determining their future job prospects [31]. Compensation, global assignment opportunities, flexible working conditions, and job security are important factors for all age groups [39]. 
The company can build, improve and maintain the company's positive image and perception to job seekers and existing employees. Organizational attributes were positively correlated to intention to apply [6]. The company can raise and increase the attraction and engagement of external parties, namely job seekers. The organization needs to manage its image to maximize recruiting effectiveness and attract job seekers or applicants [4, 40]. For the internal party (employees), employer brand can increase retention and engagement. The employee can feel that the company offers what is not in other companies offered. The relationship can develop long term engagement for the employee. In building employer branding, the company must clearly define the employee value proposition (EVP). The company's value will be the difference and uniqueness that is not owned by other companies. This research has confirmed the relationship between person-organization fit and intention to apply. Individuals who perceive a strong fit with an organisation will be attracted to apply and join that organization [7]. Employer branding actually adjusts the expectation of the employee/prospective worker to the company's attributes. Expectations are formed from their value.

\section{MANAGERIAL IMPLICATIONS}

COVID-19 has caused uncertainty in business, especially among the startup business. The startup can use these steps in the pandemic:

Adjust the current situation. Is employer branding still needed during the COVID-19 crisis while at the same time the company must cut the HRM budget? This question is difficult to answer. Employer branding can actually be implemented on a low budget. The companies can see the COVID-19 outbreak as an opportunity to better understand and potentially increase their branding through social and digital, it will be important for them to take a moment, breathe, and review their current branding to make adjustments based on the existing condition. Many companies decide to postpone hiring and some HR activities until conditions stabilize. Companies may make a budget shift to save financial conditions.

Transparency and do not oversell. The company can tell about how the company is managing the situation. However, do not try to sell too much because there will be time for that. Posting too often will slowly reduce public attention. The best way for companies now is to have empathy and support for each other. The company can focus on the employer branding elements, create effective channels in informing the employer branding elements (example social media and content), inform the company action in managing the situation, and adjust HR strategy especially about the hiring process, including the career website. COVID-19 can be an opportunity for companies to display the employee value proposition that has been built. In the survey conducted by universumglobal, $50 \%$ of organizations have added COVID-19 statements to their career websites.

Focus on the strongest dimensions of employer branding. Based on this study, The HR manager can focus on work values, diversity, and salary and incentives in building the company image (brand) as an employer. This would help them evaluate how the employer brand dimensions can help in bringing out positive outcomes in prospective candidates. They will accept a new job because of 5 top considerations: (1) work culture and team dynamics, (2) employee benefit, (3) new challenges and industry exposure, (4) maximization of skills and abilities, and (5) monetary benefits.

Focus on company image. The second implication is to use COVID-19 as a moment to prove company concern with employees. COVID-19 tested the company in some aspects including human resources management. The test is not just a decrease in losing the potential income (decrease revenue) but also in the company's image. In the COVID-19 pandemic, the company's actions were in the spotlight of the community. From this condition, the company's commitment to the employee is being tested, whether the company really cares about its employees. Many companies in Indonesia strive to maintain their image as good employers. Many young people (potential employees in the future) see what the company is doing, both in the contributions to society and to its employees.

Leadership and humanize. Amid the turbulent times, the role of the leader becomes the center of attention in making the right decisions. The decision includes how to determine the company's direction in short-term and long-term. The leader will be seen as someone who is able to carry the company like a ship full in high waves. The leader policy in COVID-19 will probably always be remembered in the future for all parties. Is the leader able to bring the company through this situation? The leader may make decisions that some people do not like, but the leader's capacity will really be tested in this situation. The human side will influence his decision. The leader may make unpopular decisions throughout his career. The leader will bring the image of the company as a brand. The leader will take the crucial role in increasing the employer brand. Leaders will sometimes be faced with the choice of saving the company, saving employees, or can save both.

Digital channel. Digital channels can be a crucial information distribution for the company. The COVID19 crisis caused many people to shift their activities at home. Many people spend a lot of time with their smartphones and computers at home. This opportunity can be used to build the company's image in the public in digital context. Companies can communicate their 
commitment during this crisis to improve positive images in cyberspace such as social media, websites, and other media. As found in this study, commitment can be in the form of CSR in supporting the handling of COVID-19 can be a priority for the company at this time. Budget cuts have indeed become unavoidable but this crisis can be an opportunity for companies to build a top of mind both within the internal and external. Companies can implement the right tactics to use including live content, user videos, FAQs, and podcasts. However, keep in mind to avoid increasing the frequency of posts and humorous posts. The themes raised should focus on positive messages and practical advice especially sending messages about what the company is doing to help the situation or to support the safety and welfare of the organization and employees. Relevant posts on social media can attract job seekers and potential customers to explore the website.

\section{CONCLUSION}

This paper presented a framework that explained the role of employer branding in the labor market in giant startup companies in Indonesia. The framework provided theoretical and practical context, especially in unpredictable conditions in COVID-19. This study confirmed the positive relationship between several dimensions of employer branding (work values, diversity, and salary, and incentives) and intention to apply in giant startup companies in Indonesia. The company can focus on employer branding as a longterm strategy. To minimize the cost, the company can only focus on the vital dimension in employer branding. The strongest dimensions are the critical variables in employer branding or a vital tool to compete in the talent war in the future. Companies can use the COVID19 situation as an opportunity to increase awareness of the brand image as an employer. The company can build a company's reputation following company goals. Employer branding can help companies improve reputation, which in turn can attract more of the best talent in the labor market to join. In other results of this study, work culture, diversity, and ethics and CSR have a significant effect on person-organization fit. The HR managers could focus on work values, diversity, and salary and incentives in promoting the company profile as an employer in attracting potential candidates or prospective employees companies can focus on the strongest dimensions of employer branding, keep in leadership and humanize in maintaining the situation, focus on company image, and use digital channel as information channel.

\section{ACKNOWLEDGEMENTS}

We would like to thank Universitas Negeri Malang that has supported and covered the fund of this research.

\section{REFERENCES}

[1] S. Davis et al, e-Conomy SEA 2019, Swipe up and to the right: Southeast Asia's $\$ 100$ billion Internet Economy, Google \& Temasek, 2019

[2] R. M. Qibthiyyah, S. Sabrina, N. A. Desdiani, T. Riefky, A. Cesarina, and M. Husna, Seri Analisis Makro Ekonomi: Rapat Dewan Gubernur Bank Indonesia. Indonesia: LPEM FEB UI, 2020

[3] https://layoffs.fyi/tracker/

[4] E. Alnıaçık and Ü. Alnıaçık. "Identifying dimensions of attractiveness in employer branding: effects of age, gender, and current employment status," Procedia - Social and Behavioral Sciences, vol. 58, pp. 1336-1343, 2012. https://doi.org/10.1016/j.sbspro.2012.09.1117

[5] D. Turban, M. Forret, and C. Hendrickson, "Applicant attraction to firms: influences of organization reputation and organizational attributes, and recruiter behaviors," Journal of Vocational Behavior, vol. 52, pp. 24-44, 1998.

[6] D. Gomes and J. Neves, "Organizational attractiveness and prospective applicants' intentions to apply," Personnel Review, vol. 40, no. 6, pp. 684-699, 2011. https://doi.org/10.1108/00483481111169634

[7] S. Terjesen, S. Vinnicombe, and C. Freeman, "Attracting Generation Y graduates: Organisational attributes, likelihood to apply and sex differences," Career Development International, vol. 12, no. 6, pp. 504-522, 2007. https://doi.org/10.1108/13620430710821994

[8] C. Igel and V. Urquhart, "Generation Z, meet cooperative learning," Middle School Journal, vol. 43, no. 4, pp. 16-21., 2016

[9] S. A. Valentic, Q\&A: How generation $Z$ is shapping the workforce. EHS Today, October 2019.

[10] A. Warmerdam, I. Lewis, and T. Banks, "Gen Y recruitment: understanding graduate intention to join an organization using theory of planned behavior," Education + Training, vol. 57, no. 5, pp. 560-574, 2015.

[11] L. K. Kuron, S. T. Lyons, L. Schweitzer, and E. S. $\mathrm{Ng}$, "Millennials's work values: differences across th school to work transition," Personal Review, vol. 44, no. 6, pp. 991-1009, 2015

[12] D. M. Cable and D. B. Turban, "Establishing the dimensions, sources and value of job seekers' 
employer knowledge during recruitment," Research in Personnel and Human Resources Management, vol. 20, pp. 115-163, 2001.

[13] H. Gilani, and S. Jamshed, "An exploratory study on the impact of recruitment process outsourcing on employer branding of an organisation," Strategic Outsourcing: An International Journal, vol. 9, no. 3, pp. 303-323, 2016

[14] S. Highhouse, F. Lievens, and E. F. Sinar, "Measuring attraction to organizations," Educational and Psychological Measurement, vol. 63, no. 6, pp. 986-1001, 2003. https://doi.org/10.1177/0013164403258403

[15] S. Alshathry, M. Clarke, and S. Goodman, "The role of employer brand equity in employee attraction and retention: a unified framework," International Journal of Organizational Analysis, vol. 25, no. 3, pp. 413-431, 2017.

[16] M. E. Brooks and S. Highhouse, "Familiarity breeds ambivalence," Corporate Reputation Review, vol. 9, no. 2, pp. 105-113, 2006.

[17] S. Helm, "Employees' awareness of their impact on corporate reputation," Journal of Business Research, vol. 64, no. 7, pp. 657-663, 2011

[18] J. Dalton and S. Croft, Managing corporate reputation. London: Thorogood, 2003.

[19] W. W. Tang, "Impact of corporate image and corporate reputation on customer loyalty. A review," Management Science and Enginerring, vol.1, no. 2, pp. 57-62, 2007.

[20] N. Nguyen, and G. Leblanc, "Corporate image and corporate reputation in customers' retention decisions in services," Journal of retailing and Customer Services, vol. 8, no. 4, pp. 227-236., 2001.

[21] B. Afsar, Y. Badir, and M. M. Khan, "Person-job fit, person-organization fit and innovative work behavior: The mediating role of innovation trust," Journal of High Technology Management Research, vol. 26, no. 2, pp. 105-116, 2015. https://doi.org/10.1016/j.hitech.2015.09.001

[22] H. M. Choi, W. G. Kim, and S. McGinley, "The extension of the theory of person-organization fit toward hospitality migrant worker," International Journal of Hospitality Management, vol. 62, pp. 53-66,

2017.

https://doi.org/10.1016/j.ijhm.2016.12.003

[23] M. S. Farooqui, and A. Nagendra, "The impact of person organization fit on job satisfaction and performance of the employees," Procedia
Economics and Finance, vol. 11, pp. 122-129, $2014 . \quad$ https://doi.org/10.1016/s2212$\underline{5671(14) 00182-8}$

[24] A. M. Ryan, and R. E. Ployhart, "Applicants' perceptions of selection procedures and decisions: A critical review and agenda for the future," Journal of management, vol. 26, no. 3, pp. 565606,2000

[25] T. Jiang, and P. Iles, "Employer-brand equity, organizational attractiveness and talent management in the Zhejiang private sector, China," Journal of Technology Management in China, vol. 6, no. 1, pp. 97-110, 2011 https://doi.org/10.1108/17468771111105686

[26] R. Sharma, A. Prasad, "Employer brand and its unexplored impact on inten to join," International Journal of Organizational Analysis, vol. 26, no. 3, pp. 536-566, 2018.

[27] C. Xie, R. P. Bagozzi, K. V. Meland, "The impact of reputation and identity congruence on employer brand attractiveness," Marketing Intelligence \& Planning, vol. 32, no. 2, pp. 124-146, 2015. https://doi.org/10.1108/02634501011078138

[28] R. B. Kline, Principles and practice of structural equation modelling, $2^{\text {nd }}$ Ed. New York: The Guilford Press, 2005.

[29] P. M. Bentler and C-P. Chou, "Practical Issues in Structural Modeling," Sociological Methods \& Research, vol. 16, no. 1, pp. 78-117, 1987. doi:10.1177/0049124187016001004

[30] K. Tanwar, and A. Kumar, "Employer brand, person-organisation fit and employer of choice: Investigating the moderating effect of social media," Personnel Review, vol. 48, no. 3, pp.799823,2019 .

[31] J. Santiago, "The relationship between brand attractiveness and the intent to apply for a job: A millennials' perspective," European Journal of Management and Business Economics, vol. 28, no. 2, pp. 142-157, 2019. https://doi.org/10.1108/EJMBE-12-2018-0136

[32] S. E. Myrden and K. Kelloway, 'Young workers' perception of brand image: main and moderating effects Susan," Journal of Organizational Effectiveness: People and Performance, vol. 2, no. 3, pp. 244-266, 2015.

[33] K. Tanwar, and A. Prasad, "Employer brand scale development and validation: a second-order factor approach," Personnel Review, vol. 46, no. 2, pp. 389-409, 2017. https://doi.org/10.1108/PR-032015-0065 
[34] J. F. Hair, W. C. Black, B. J. Babin, R. E. Anderson, and R. L. Tatham, Multivariate data analysis, Vol. 6. Upper Saddle River, NJ: PrenticeHall, 2006.

[35] L. Lindholm, "The use of corporate social responsibility in employer branding," In N. Koporcic, M. Ivanova-Gogne, A.-G. Nyström, and J.-Å. Törnroos (Ed.) Developing Insights on Branding in the B2B Context, Emerald Publishing Limited, pp. 3-93, 2018.

[36] B. A. Miraja, S. F. Persada, Y. T. Prasetyo, P. F. Belgiawan, and A. A. N. P. Redi, "Applying protection motivation theory to understand generation $\mathrm{Z}$ students intention to comply with educational software anti piracy law," International Journal of Emerging Technologies in Learning, vol. 14, no. 18, pp. 39-53, 2019.

[37] C. C. Lee, R. H. Kao, and C. J. Lin, "A study on the factors to measure employer brand: the case of undergraduate senior students," Chinese Management Studies, vol. 12, no. 4, pp. 812-832, 2018. https://doi.org/10.1108/CMS-04-2017-0092

[38] R. E. Basham, and F. R. Buchanan, "A survey comparation of career motivations of social work and business students," Journal of Social Work Education, vol. 45, no. 2, pp. 187-208, 2009.

[39] J. Neetu, and B. Prachi, "Employment preferences of job applicants: unfolding employer branding determinants," Journal of Management Development, vol. 34, no. 6, pp. 634-652, 2015.
[40] F. Lievens and S. Highhouse, "The relation of instrumental and symbolic attributes to a company's attractiveness as an employer," Personnel Psychology, vol. 56, no. 1, pp. 75-102, $2003 . \quad$ https://doi.org/10.1111/j.1744$\underline{\text { 6570.2003.tb00144.x }}$

[41] P. Berthon, M. Ewing, and L. L. Hah, "Captivating company: dimensions of attractiveness in employer branding," International Journal of Advertising, vol. 24, no. 2, pp. 151-172, 2005.

[42] T. Schlager, M. Bodderas, P. Maas, and J. L. Cachelin, "The influence of the employer brand on employee attitudes relevant for service branding: an empirical investigation," Journal of Services Marketing, vol. 25, no. 7, pp. 497-508, 2011.

[43] A. Sivertzen, E. R. Nilsen, E. R., and A. H. Olafsen, "Employer branding: employer attractiveness and the use of social media," Journal of Product \& Brand Management, vol. 22, no. 7, pp. 473-483, 2013

[44] J. Sullivan, "Eight elements of a successful employment brand," ER Daily, 23, pp. 501- 517, 2004 